OPEN ACCESS

Citation: A. Farashi, Z. Karimian (2021) Predicting the potential habitat of Russian-Olive (Elaeagnus angustifolia) in urban landscapes. Italian Journal of Agrometeorology (1): 3-19. doi: 10.36253/ijam-1071

Received: September 5, 2020

Accepted: November 14, 2020

Published: August 9, 2021

Copyright: (c) 2021 A. Farashi, Z. Karimian. This is an open access, peerreviewed article published by Firenze University Press (http://www.fupress. com/ijam) and distributed under the terms of the Creative Commons Attribution License, which permits unrestricted use, distribution, and reproduction in any medium, provided the original author and source are credited.

Data Availability Statement: All relevant data are within the paper and its Supporting Information files.

Competing Interests: The Author(s) declare(s) no conflict of interest.

Funding: This study was funded by the Vice-Presidency for Science and Technology of Iran (grant number 96002787)

Author contributions statement: All authors contributed to the study conception and design. Material preparation, data collection and analysis were performed by Azita Farashi and Zahra Karimian. The first draft of the manuscript was written by Azita Farashi and all authors commented on previous versions of the manuscript. All authors read and approved the final manuscript.

\section{Predicting the potential habitat of Russian- Olive (Elaeagnus angustifolia) in urban landscapes}

\author{
AZITA FARASHi $^{1}$, ZAHRA KARIMIAN ${ }^{2}$ \\ ${ }^{1}$ Department of Environmental Sciences, Faculty of Natural Resource and Environment, \\ Ferdowsi University of Mashhad, Mashhad, Iran \\ ${ }^{2}$ Department of Ornamental Plants, Research Center for Plant Sciences, Ferdowsi Univer- \\ sity of Mashhad, Iran \\ E-mail: farashi@um.ac.ir; zkarimianf@gmail.com
}

\begin{abstract}
Russian-olive (Elaeagnus angustifolia) is a species native to southern Europe and central and eastern Asia. This species plays an important role in urban landscape design because of its rapid growth, resistance in harsh climates and tolerance to human-caused pressure. Understanding its potential dispersal and restricting parameters are the first steps toward the sustainable use of this species. Here, we used Species Distribution Models to predict the potential distribution of Russian-olive in Iran climate and estimate the possible limiting factors for its spread. Our results highlighted the importance of environmental variables including climatic factors, soil, and lithology in the distribution of this species throughout the country. According to these results, suitable habitats for Russian-olive are located in the north of Iran along the Alborz and Koppeh-Dagh mountain ranges. Therefore, the suitable habitats for this species are limited to only nine percent of the country. A habitat suitability map can be used to evaluate future developments in urban areas and predict the dispersal range of Russian-olive in Iran. Our results show that Russian-olive can be used to create new green spaces in urban climates in the northern regions of Iran.
\end{abstract}

Keywords: climate, green space, ornamental tree, SDM, urban areas.

\section{INTRODUCTION}

The Middle East and North Africa are home to five percent of Earth's human population. However, only one percent of the global freshwater resources is located in Middle Eastern and North African countries (Djuma et al. 2016). As a result, water scarcity looms large across the region (Al-Ansari and Knutsson 2011; Al-Ansari et al. 2014; Abbas et al. 2018). To complicate the problem even further, population growth and political tensions threaten the sustainability of existing water resources in the Middle East and North Africa (Djuma et al. 2016).

Consequently, making use of different water sources and enhancing the resilience of water supply is crucial to meet the needs of the increasing urban population (Bichai et al. 2015). The environmental damage associated with urban devel- 
opment has drawn attention to the need for green spaces in cities, which will lead to increased water use (Zhang et al. 2017). Green spaces are among the indicators of sustainable urban development. When planning for urban green spaces, numerous elements, such as economic, political, social, and cultural factors, along with management and planning considerations need to be taken into account (Haq 2011). Conservation of biological resources and maintaining soil and water quality are among the services provided by urban green spaces (Haq 2011, 2015). Many studies indicate that plant particularly trees can improve the urban microclimate and influence thermal comfort in various ways including shading, controlling the humidity, wind break, pollutant absorption and produce oxygen (Abreu- Harbich et al. 2015; Thoma et al. 2016; Afshar et al., 2018).

In arid regions such as the Middle East, design of urban green spaces is one of the main challenges facing city planners and urban architects. One solution to address this challenge is the use of native plant species which are adapted to the dry conditions of the region (Katz and Shafroth 2003; Kiseleva and Chindyaeva 2011).

The first step in utilizing native species is identification of their habitat requirements. Species distribution models (SDMs) trace their origin to the 1970s and have remained a common tool for ecologists throughout the following decades (e.g., Guisan and Zimmermann 2000; Guisan and Thuiller 2005; Rooper et al. 2016). In the time since their conception, several SDM algorithms have been developed, as discussed by Elith and Leathwick (2009) and Farashi and Alizadeh-Noughani (2018). These algorithms distinguish the major variables that determine a species' suitable habitat and show how predictor variables impact response variables. Furthermore, SDM algorithms enable researchers to see species' potential distribution (Liang and Stohlgren, 2011; Liang et al. 2017). Through modifications, these algorithms have been optimized for use in fields such as biogeography, ecology, evolution, and species conservation and management (Mikolajczak et al., 2015; Hannah et al., 2015). SDMs have also been used to assess the potential distribution of plant species (e.g., Kumar and Stohlgren 2009; Hemsing and Bryn 2012; Zhang et al., 2013; Guida et al. 2014; Hu et al. 2018). In the present study, we have used SDMs to predict the spatial distribution of Russian-olive (Elaeagnus angustifolia), a native plant species in Iran. Iran is a Middle Eastern country located on Earth's arid belt with upwards $60 \%$ of the country's area having an arid or semi-arid climate. In areas that receive little precipitation and experience severe fluctuations from year to year, agriculture is often limited by water availability (Modarres and da Silva 2007).

Russian-olive is native to Eurasia that occurs on coasts, in riparian areas, along watercourses, in other rela- tively moist habitats and also in many arid and semiarid regions of the world (Klich, 2000; Peterson et al., 2003). Soil salinity (low to medium concentrations), $\mathrm{pH}$ and water supply and moisture (low) are important environmental factors in Russian-olive habitat (Carman, 1982; Zitzer and Dawson, 1992; Reynolds and Cooper, 2010; Dubovyk et al., 2016). Russian-olive is resistant to drought $\left(+46{ }^{\circ} \mathrm{C}\right)$ and frost $\left(-46^{\circ} \mathrm{C}\right)$ (Stratu et al., 2016; Akbolat et al., 2008). This tree is an ecologically valuable plant that are adapted to a variety of harsh conditions such as cold, drought, and salinity or alkalinity of soil (Asadiar et al. 2013; Zhang et al. 2018). The species endures through water scarcity by using groundwater (Katz and Shafroth 2003). Along with its desirable ecological characteristics, Russian-olive possess aesthetic values such as its beautiful oval crown, arching branches, silver leaves and shiny dark red fruits. Therefore E. angustifolia is particularly suitable for urban landscapes in arid regions such as Iran. This tree can be used to create sustainable green spaces in urban climates of Iran.

\section{MATERIALS AND METHODS}

\section{Study area and species}

Iran is located in Western Asia between $24^{\circ}-40^{\circ} \mathrm{N}$ and $44^{\circ}-64^{\circ}$ E. Due to its habitat diversity and phytogeographic variety, Iran hosts rich biodiversity. Over 8,000 species of plants are found in Iran, of which 1,810 are endemic (Ghahraman and Attar 2000; Willis 2001). Russian-olive is a deciduous tree, sometimes with a shrubby habit, in the family Elaeagnaceae (Saboonchian et al. 2014). This species naturally grows in central and eastern Asia and southern Europe. Russian-olive grows quickly, reaching a maximum height of $10 \mathrm{~m}$ and maximum trunk diameter of $30 \mathrm{~cm}$. Trees usually bear fruit after 5-6 years (Katz and Shafroth 2003).

\section{Species distribution models}

SDMs were developed in Biomod2 package (Thuiller et al. 2009, 2014) in R version 3.1.25 ( $\mathrm{R}$ Core Team 2014). 10 different algorithms were used to study the species (Tab. 1). The algorithms can be categorized as: regression, machine learning, classification and enveloping algorithms. Regression-based algorithms include generalized linear models (GLMs) and generalized additive models (GAMs) which generate linear and non-linear equations between presence data and environmental variables, respectively. Machine learning algorithms include artificial neural networks (ANN), boosted regression trees, (BRT), multivariate adaptive regression splines (MARS), maximum 
Table 1. The SDM algorithms in biomod ${ }^{2}$ used in this study.

\begin{tabular}{ccccc}
\hline SDM & Variable & Type & Reference & TSS \\
\hline ANN & Artificial neural networks & P/A & Lek and Guégan (1999) & 0.71 \\
BRT & Boosted regression trees & P/A & Elith et al. $(2008)$ & 0.71 \\
CART & Classification and regression trees & P/A & Vayssières et al. (2000) & 0.60 \\
FDA & Flexible discriminant analysis & P/A & Hastie et al. (1994) & 0.72 \\
GAM & Generalized additive models & P/A & Guisan et al. (2002) & 0.60 \\
GLM & Generalized linear models & P/A & Guisan et al. (2002) & 0.70 \\
MaxEnt & Maximum entropy & P/B & Phillips et al. (2006) & 0.80 \\
MARS & Multivariate adaptive regression splines & Priedman (1991) & 0.61 \\
RF & Random forest & P/A & Breiman (2001) & 0.65 \\
SRE & Surface range envelope & P/B & Busby (1991) & 0.65 \\
Ensemble & - & - & Araújo and New (2007) & 0.85 \\
\hline
\end{tabular}

P: Presence; A: Absence; B: Background.

entropy (MaxEnt), and random forest (RF). Machine learning algorithms directly generate the environmental space using input data. Classification algorithms such as classification and regression trees (CART) and flexible discriminate analyses (FDA) successively divide data into homogenous partitions. Surface range envelope (SRE), the only enveloping method used in this study, investigates environmental conditions at the points of occurrence and uses the results to find similar areas (Merow et al. 2014).

Variable importance was calculated by a permutation procedure used in biomod, which is independent of the modelling technique. Once the models were trained (i.e., calibrated), a standard prediction was made. Then, one of the variables was randomized and a new prediction was made. The correlation score between the new prediction and the standard prediction was calculated and gave an estimation of the variable importance in the models (Thuiller et al., 2009).

Models were evaluated using the True Skill Statistic (TSS). TSS is the sum of sensitivity and specificity minus 1 , and does not depend on prevalence (Allouche et al. 2006; Fielding and Bell 1997). TSS was used to create an ensemble-forecasting framework, as per Araújo and New (2007). All models contributed to the ensemble model. However, those with better performance, as indicated by TSS, were given more weight (Thuiller et al. 2009). A threshold value was defined by maximizing training sensitivity and specificity in order to create a binary (presence/absence) map from outputs of the algorithms (Liu et al. 2005; Liu et al. 2011). Sensitivity and specificity are statistical index of the performance of a binary classification analysis. Sensitivity calculate the proportion of actual presences which are correctly predicted as such, while specificity calculate the proportion of pseudoabsences which are predicted as absences. By maximizing the sum of sensitivity and specific- ity, the associated threshold corresponds to the point on the ROC curve (i.e. sensitivity against 1-specificity) whose tangent slope is equal to 1 (Kaivanto 2008; Jiguet et al. 2011). The approach was selected to calculate the threshold for presence/absence predictions in biomod2 (Liu et al. 2005).

\section{Presence data and environmental variables}

Occurrence records and distribution of the species were obtained from herbariums of Ferdowsi University of Mashhad, Tehran University, and University of Birjand. Flora Iranica (Rechinger, 1963-2015) and Flora of Iran (Assadi et al. 1988-2017). Herbaria data were obtained from field samplings between 2009 and 2019. The coordinates of all the occurrence points were recorded using a hand-held multichannel Global Positioning System (GPS) receiver with a positional accuracy of $\pm 5 \mathrm{~m}$. The spatially correlated presence points were removed using spatial autocorrelation and Moran's I test. The number of presence points was 83 (Fig. 1).

Topographic, geographic, edaphic, and climatic variables were used as input for the algorithms. Topographic variables were obtained from the national cartographic center of Iran (NCC) at 1-km spatial resolution. Geological survey and mineral exploration of Iran (GSI) provided the geographic data at $1-\mathrm{km}$ spatial resolution. Edaphic variables were accessed from the agricultural research, education and extension organization of Iran (AREEO) at $1-\mathrm{km}$ spatial resolution.

Mean elevation and mean slope for all raster cells in a $1-\mathrm{km}$ radius were the two topographic variables used in modeling. Geographic and edaphic variables included soil orders and lithology, respectively. An initial set of 20 
Table 2. Environmental predictors and their relative contributions to ensemble model of E. angustifolia.

\begin{tabular}{|c|c|c|}
\hline Environmental variables & Mean + SD & Relative contribution (\%) \\
\hline \multicolumn{3}{|l|}{ Climatic variables } \\
\hline Mean Diurnal Range ${ }^{1}\left({ }^{\circ} \mathrm{C}\right)$ & $38.01 \pm 3.08$ & 4.0 \\
\hline Temperature Seasonality ${ }^{2}$ & $8162.63 \pm 995.89$ & 0.3 \\
\hline Mean Temperature of Warmest Quarter $\left({ }^{\circ} \mathrm{C}\right)$ & $27.26 \pm 4.49$ & 22.3 \\
\hline Mean Temperature of Coldest Quarter $\left({ }^{\circ} \mathrm{C}\right)$ & $6.39 \pm 5.87$ & 1.0 \\
\hline Annual Precipitation (mm) & $208.13 \pm 140.89$ & 0.1 \\
\hline Precipitation of Wettest Quarter (mm) & $111.34 \pm 64.48$ & 0.4 \\
\hline Precipitation of Driest Quarter (mm) & $5.86 \pm 13.09$ & 1.1 \\
\hline Annual solar radiation $\left(\mathrm{kJ} \mathrm{m}^{-2}\right.$ day $\left.^{-1}\right)$ & $10743.56 \pm 1906.88$ & 10.2 \\
\hline \multicolumn{3}{|l|}{ Topographic variables } \\
\hline Altitude (m) & $1251.24 \pm 686.64$ & 0.2 \\
\hline Slope (degree) & $6.20 \pm 7.93$ & 0.6 \\
\hline \multicolumn{3}{|l|}{ Geographic variable } \\
\hline Lithology & 557 classes & 50.2 \\
\hline \multicolumn{3}{|l|}{ Edaphic variable } \\
\hline Soil order & 20 classes & 8.5 \\
\hline
\end{tabular}

${ }^{1}$ Mean of monthly (max temp - min temp).

${ }^{2}$ Standard deviation $\times 100$.

climatic variables, including precipitation, temperature, and solar radiation were obtained from the Worldclim database (http://www.worldclim.org). Climatic variables were used at a resolution of $30 "$ ( 1 km). The correlation between all pairs of variables was tested. If $-0.7>\mathrm{r}>+0.7$, one of the two variables was excluded from the input data. The correlation tests reduced the number of variables to 12 , which were subsequently used to model habitat suitability (Tab. 2).

\section{RESULTS}

All ten models showed a relatively good performance predicting the distribution of Russian-olive (Tab. 1). The results of modeling evaluation based on the TSS values showed that the combination of models performed relatively better than each individual model. Moreover, a model evaluation test showed that ensemble model performed better than other distribution models. The distribution map obtained from the ensemble model has been presented in Fig. 1. Our results showed that most of the suitable habitats for Russian-olive are located in the north of Iran. Only 9.5 percent of the country was suitable to grow this species (Fig. 1).

Suitable habitats based for each province have been presented in a separate map (Fig. 2). North Khorasan had the highest, and Ilam and Bushehr had the lowest proportion of suitable habitats among all provinces (Fig. 2). The

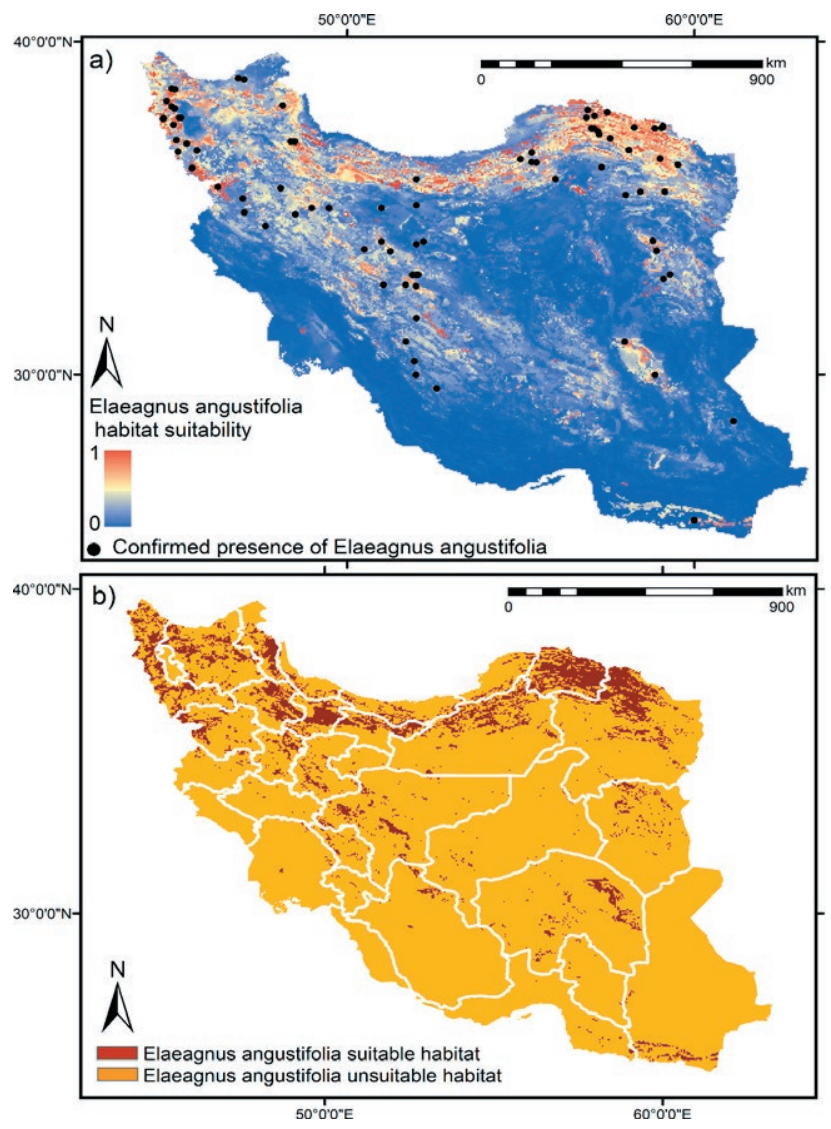

Fig. 1. Habitat suitability of E. angustifolia and its suitable habitats in Iran using ensemble model (a: continuous map, b: categorical map). 


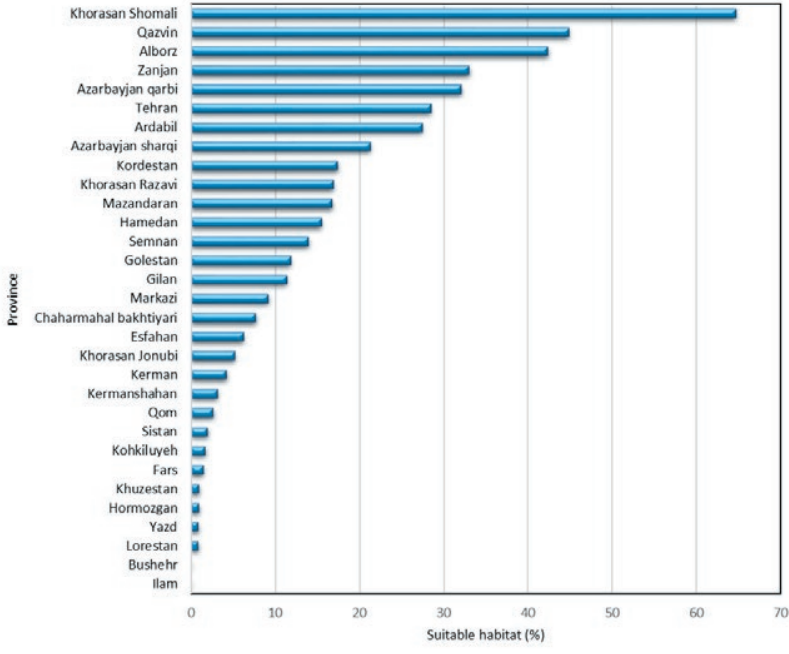

Fig. 2. Suitable habitats of E. angustifolia in each province. relative importance of environmental variables changed based on different models. According to ensemble model, the most important environmental variables to predict habitat suitability for this species were lithology $(50 \%$ of the contribution), mean temperature of the warmest quarter (22\% of the contribution), annual solar radiation ( $10 \%$ of the contribution) and soil order ( $8 \%$ of the contribution) (Tab. 2).

Response curves for the four dominant environmental factors are shown in Fig. 3. There are unimodal relationships between habitat suitability and annual solar radiation. Peak presence probability was observed at $8150 \mathrm{~kJ}$ $\mathrm{m}^{-2}$ day $^{-1}$. The relationship between the habitat suitability values and mean temperature of the warmest quarter was best described by an exponential decay with the peak response at $5-7^{\circ} \mathrm{C}$. The results also demonstrated that any increase in mean temperature of the warmest quarter and

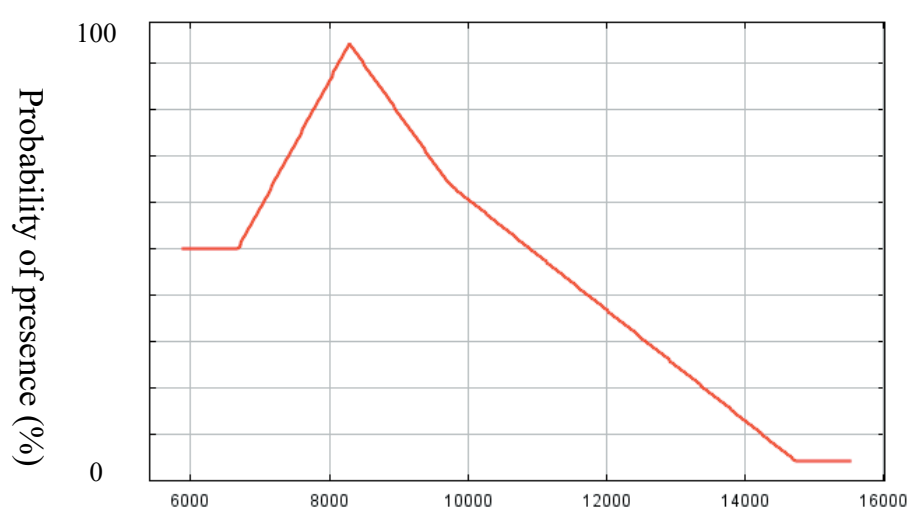

Annual solar radiation $\left(\mathrm{kJ} \mathrm{m}^{-2}\right.$ day $\left.^{-1}\right)$

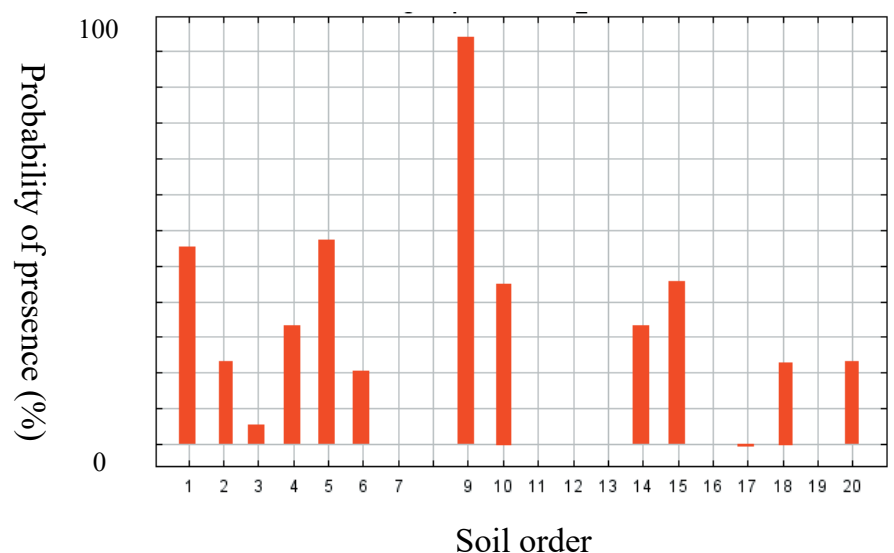

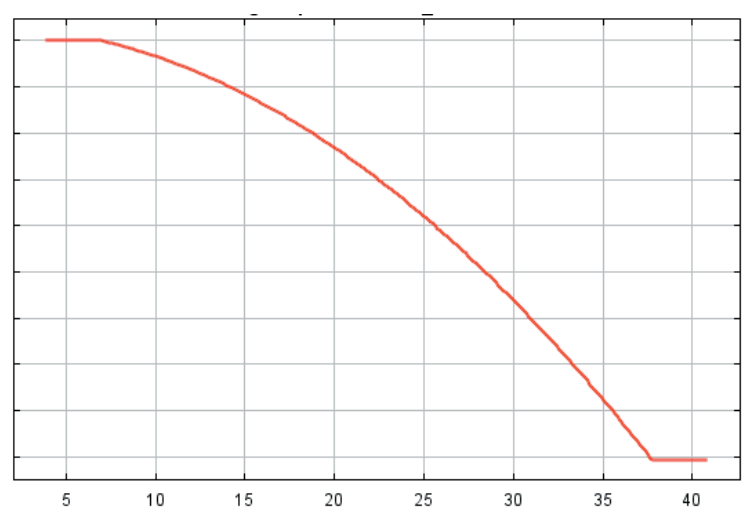

Mean Temperature of Warmest Quarter $\left({ }^{\circ} \mathrm{C}\right)$

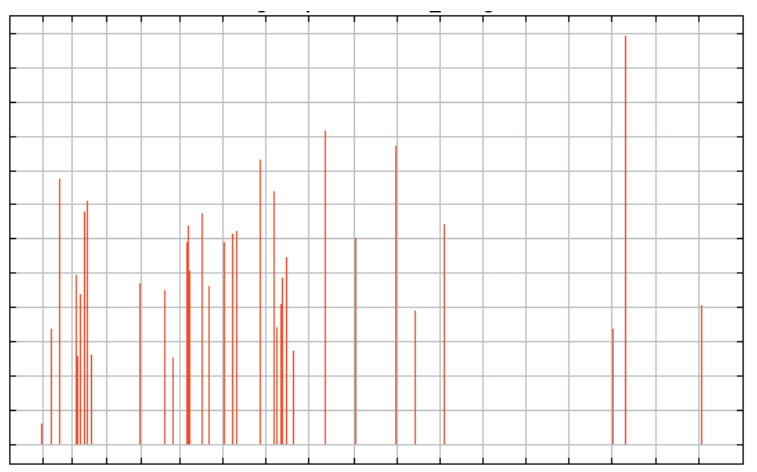

$\begin{array}{lllllllllllllllllll}1 & 26 & 54 & 83 & 115 & 151 & 187 & 223 & 261 & 296 & 332 & 368 & 403 & 439 & 475 & 512 & 547\end{array}$

Lithology

Fig. 3. Response curves of environmental variables for E. angustifolia (see soil order and lithology legend in supplementary file, Class 9 in soil order: rocky lands, Class 488 in lithology: high-level piedmont fan and valley terrace deposits). 
annual solar radiation led to a decrease in habitat suitability for Russian-olive.

The relationship between the habitat suitability values with soil order and lithology showed that this species could grow in different soil and rock classes. However, the highest presence probability is observed in rocky lands and high-level piedmont fan and valley terrace deposits (Fig. 3).

\section{DISCUSSION}

Iran is a large country, containing a variety of climates. While the northern regions have a temperate climate, southern regions are dry and frequently experience droughts and water scarcity (Abbaspour et al., 2009; Bannayan et al., 2010). Our results show the prominent role of mean temperature of warmest quarter, annual solar radiation, lithology, and soil order in creating a suitable habitat for Russian-olive. The contribution of other variables was not considerable. Previous studies have shown that Russian-olive is capable of growing under both flooded and drought conditions in its native range (Asadiar, et al., 2013, Stannard et al., 2002) as well as its introduced range (Katz and Shafroth, 2003; Reynolds and Cooper, 2010). E. angustifolia's extensive root network allows it to utilize moisture stored in deep soil or groundwater (Cui et al., 2015; Dubovyk et al., 2016). Owing to insufficient hydro-geological data, we could not use these variables in our study. Nevertheless, we recommend including them in future studies when they become available for Iran.

Our findings also reveal the importance of environmental variables such as soil (soil orders) and lithology in determining suitable habitats for Russian-olive, which supports the findings of previous studies (Zitzer and Dawson, 1992; Carman and Brotherson, 1982; Khamzina et al., 2009; Collette and Pither, 2015). The results demonstrate how Russian-olive can survive only under certain climatic conditions but can continue to grow on a number of soil orders and lithological formations (Lesica and Miles 2001; Katz and Shafroth, 2003; Reynolds and Cooper 2010; Collette and Pither, 2015). This makes Russian-olive a good candidate for shelterbelts in different regions (Olson and Knopf 1986; Pearce et al., 2009).

Roughly $9 \%$ of Iran is suitable habitat for Russian-olive, stretching along the Alborz and Koppeh-Dagh mountain ranges (Fig. 1). The Alborz and Koppeh-Dagh are comparable with temperate European mountain ranges such as the Alps in terms of endemism (Tribsch and Schonswetter 2003; Noroozi et al. 2008, 2018). Iranian provinces vary regarding habitat suitability for Russian-olive. All provinces, with the exception of Ilam and Bushehr (in the west and south of Iran, respectively), contained suitable habi- tats for Russian-olive. North Khorasan (64.7\%), Qazvin (44.8\%), and Alborz (42.4\%) had the highest proportion of suitable habitats for Russian-olive. Suitability maps can inform future urban development and predict the future range of Russian-olive.

Therefore, it is suggested to protect the critical habitats of Russian-olive and use this species in urban green spaces. Russian-olive is not a demanding species and can survive for 50-80 years in different conditions. E. angustifolia is used to as a soil stabilizer, a hedge plant, and a fragrant ornamental. Due to its characteristics, Russian-olive is used in shelterbelts and urban landscapes (Kolesnikov, 1974; Kiseleva and Chindyaeva, 2011).

Russian-olive can become invasive (Reynolds and Cooper, 2010; Collette and Pither, 2015). After its introduction as an ornamental plant, Russian-olive became invasive in the US and Canada in the early $20^{\text {th }}$ century (Katz and Shafroth 2003). The species negatively affected riparian forests and, as a result, was declared a noxious species in Colorado and New Mexico (Katz and Shafroth 2003; Collette and Pither, 2015). Introduction of this species to areas outside its native range should be done with caution. However, such considerations are not needed when planting Russian-olives in its native range since the species will not disrupt the natural processes of its native ecosystems (Strauss et al., 2006; Marsh-Matthews et al., 2011; Zhang et al., 2018). Moreover, native species can be advantageous to the local economy. As a result, we recommend the use of Russian-olive in urban landscapes in northern Iran.

A common assumption among SDMs is that species can only establish in areas that are ecologically similar to their native range (Kearney 2006). However, a species niche might change (Broennimann et al., 2007). As a result, the output of SDM algorithms is an approximation of species' niche in new environments. The differences in bioclimatic conditions between native areas and those we are making predictions for might lead to an underestimation of actual suitable areas. Thus, more accurate predictions can only be made by taking into account both biotic and abiotic variables and their interactions. These studies can be further improved through comparisons with areas under invasion by alien invasive species. In the meantime, the mere presence of suitable habitats for a species should not encourage managers to use the species before more extensive investigations are performed. However, the efficiency of SDMs is affected by several parameters (Allouche et al. 2008) such as the characteristics of environmental data (e.g. type, variance data; Aguirre-Gutiérrez et al. 2013), characteristics of species data (e.g. geographical accuracy, sample size, field survey constraints, or auto-correlation structure; Huettmann and Diamond 2006), species ecology (e.g. distribution range, abundance, 
niche limits of species; Saupe et al., 2012), computer power (i.e. too many cells may be too demanding on computer resources), model (e.g. presence only/presence-absence; Aguirre and Gutiérrez et al., 2013), and spatial resolution (Farashi and Naderi 2017). Despite their shortcomings, SDMs can still help us grasp the biological history of a species distribution (Silva Rocha et al., 2015). Further investigation is needed to study niche shift, distinguish the most influential variables, and pinpoint the role of other factors in determining distribution of the species.

\section{ACKNOWLEDGMENT}

This work was supported by Iran National Science Foundation [grant number 96002787].

\section{REFERENCES}

Abbas N, Wasimi S, Al-Ansari N, Sultana N 2018 Water resources problems of Iraq: Climate change adaptation and mitigation. Journal of Environmental Hydrology 26.

Abbaspour KC, Faramarzi M, Ghasemi SS, Yang H 2009 Assessing the impact of climate change on water resources in Iran. Water resources research 45(10).

Abreu-Harbich LV, Labaki LC, Matzarakis A 2015 Effect of tree planting design and tree species on human thermal comfort in the tropics. Landscape and Urban Planning 138: 99-109.

Aguirre-Gutiérrez, J., Carvalheiro, L. G., Polce, C., van Loon, E. E., Raes, N., Reemer, M., \& Biesmeijer, J. C. (2013). Fit-for-purpose: species distribution model performance depends on evaluation criteria-Dutch hoverflies as a case study. PloS one, 8(5), e63708..

Akbolat D, Ertekin C, Menges HO, Guzel E, Ekinci K 2008 Physical and Nutritional Properties of Oleaster (Elaeagnus angustifolia L.) Growing in Turkey. Asian Journal of Chemistry 20(3): 2358-2366 Al-Ansari N, Abdellatif M, Zakaria S, Knutsson S, Mustafa Y 2014 Future Prospects for Macro Rainwater Harvesting (RWH) technique in north east Iraq. Journal of Water Resource and Protection 6(5): 403-420.

Al-Ansari N, Knutsson S 2011 Toward prudent management of water resources in Iraq. Journal of Advanced Science and Engineering Research (1): 53-67.

Allouche O, Tsoar A, Kadmon R 2006 Assessing the accuracy of species distribution models: prevalence, kappa and the true skill statistic (TSS). Journal of applied ecology 43(6): 1223-1232.

Allouche, O., Steinitz, O., Rotem, D., Rosenfeld, A., \& Kadmon, R. (2008). Incorporating distance con- straints into species distribution models. Journal of Applied Ecology, 45(2), 599-609..

Araújo, M.B. New, M 2007 Ensemble forecasting of species distributions. Trends in Ecology Evolution 22: $42-47$.

Asadiar LS, Rahmani F, Siami A 2013 Assessment of genetic diversity in the Russian olive (Elaeagnus angustifolia) based on ISSR genetic markers. Revista Ciência Agronômica 44(2): 310-316.

Assadi M, Maassoumi AA, Khatamsaz M, Mozaffarian V. (Eds.) 1988-2017 Flora of Iran vols. 1-76 Research Institute of Forests and Rangelands Publications, Tehran .

Bannayan M, Sanjani S, Alizadeh A, Lotfabadi SS, Mohamadian A 2010 Association between climate indices, aridity index, and rainfed crop yield in northeast of Iran. Field Crops Research 118 (2): 105114.

Bichai F, Ryan H, Fitzgerald C, Williams K, Abdelmoteleb A, Brotchie R, Komatsu R 2015 Understanding the role of alternative water supply in an urban water security strategy: An analytical framework for decision-making. Urban Water Journal 12(3): 175-189.

Broennimann O, Treier, UA, Müller-Schärer H, Thuiller W, Peterson AT, Guisan A 2007 Evidence of climatic niche shift during biological invasion. Ecology letters 10(8): 701-709.

Carman JG, Brotherson JD 1982. Comparisons of sites infested and not infested with saltcedar (Tamarix pentandra) and Russian olive (Elaeagnus angustifolia). Weed Science 30(4): 360-364.

Collette LK, Pither J 2015 Russian-olive (Elaeagnus angustifolia) biology and ecology and its potential to invade northern North American riparian ecosystems. Invasive Plant Science and Management 8(1): 1-14.

Cui Y, Ma J, Sun W, Sun J, Duan Z 2015 A preliminary study of water use strategy of desert plants in Dunhuang, China. Journal of Arid Land 7(1): 73-81.

Djuma H, Bruggeman, A, Eliades M Lange, M A 2016 Non-conventional water resources research in semiarid countries of the Middle East. Desalination and Water Treatment 57(5): 2290-2303.

Dubovyk O, Menz G, Khamzina A 2016 Land suitability assessment for afforestation with Elaeagnus angustifolia L. In degraded agricultural areas of the lower amudarya river basin. Land Degradation Development 27(8): 1831-1839.

Elith J, Leathwick JR 2009 Species distribution models: ecological explanation and prediction across space and time. Annual review of ecology, evolution, and systematics 40: 677-697.

Farashi A, Alizadeh-Noughani M 2018 Effects of models and spatial resolutions on the species distribution 
model performance. Modeling Earth Systems and Environment 4(1): 263-268.

Farashi, A., \& Naderi, M. (2017). Predicting invasion risk of raccoon Procyon lotor in Iran using environmental niche models. Landscape and Ecological Engineering, 13(2), 229-236.

Fielding AH, Bell JF 1997 A review of methods for the assessment of prediction errors in conservation presence/absence models. Environmental conservation 24(1): 38-49.

Ghahraman A, Attar F 2001 Biodiversity of plant species in Iran. Published by Tehran University, 1, pp. 1210.

Guida RJ, Abella SR, Smith Jr WJ, Stephen H, Roberts CL 2014 Climatic change and desert vegetation distribution: Assessing thirty years of change in southern Nevada's Mojave Desert. The Professional Geographer 66(2): 311-322.

Guisan A, Thuiller W 2005 Predicting species distribution: offering more than simple habitat models. Ecology letters 8(9): 993-1009.

Guisan A, Zimmermann NE 2000 Predictive habitat distribution models in ecology. Ecological modelling 135(2): 147-186.

Hannah L, Midgley G, Davies I, Davies F, Ries L, Thuiller W, Stoms D 2015 BioMove-Improvement and Parameterization of a Hybrid Model for the Assessment of Climate Change impacts on the Vegetation of California.

Haq SMA 2011 Urban green spaces and an integrative approach to sustainable environment. Journal of environmental protection 2(05): 601.

Haq SMA 2015 Urban green spaces and an integrative approach to sustainable environment. Urban Ecology: Strategies for Green Infrastructure and Land Use; Etingoff, K., Ed, 147-16.

Hemsing L, Bryn A 2012 Three methods for modelling potential natural vegetation (PNV) compared: A methodological case study from south-central Norway. Norsk Geografisk Tidsskrift-Norwegian. Journal of Geography 66(1): 11-29.

Hu Z, Guo K, Jin S Pan H 2018 The influence of climatic changes on distribution pattern of six typical Kobresia species in Tibetan Plateau based on MaxEnt model and geographic information system. Theoretical and Applied Climatology 1-16.

Huettmann, F., \& Diamond, A. W. (2006). Large-scale effects on the spatial distribution of seabirds in the Northwest Atlantic. Landscape Ecology, 21(7), 1089-1108.

Jiguet, F., Barbet-Massin, M., \& Chevallier, D. (2011). Predictive distribution models applied to satellite tracks: modelling the western African winter range of European migrant Black Storks Ciconia nigra. Journal of Ornithology, 152(1), 111-118..
Kaivanto, K. (2008). Maximization of the sum of sensitivity and specificity as a diagnostic cutpoint criterion. Journal of clinical epidemiology, 61, 516-518.

Karimi Afshar N, Karimian Z, Doostan R, Habibi Nokhandan M 2018 influence of planting designs on winter thermal comfort in an urban park. Journal of Environmental Engineering and Landscape Management 26(3): (232-240).

Katz GL, Shafroth PB 2003 Biology, ecology and management of Elaeagnus angustifolia L. (Russian olive) in western North America. Wetlands 23(4): 763-777.

Kearney M 2006 Habitat, environment and niche: what are we modelling? Oikos 115(1), 186-191.

Khamzina A, Lamers JP, Vlek PL 2009 Nitrogen fixation by Elaeagnus angustifolia in the reclamation of degraded croplands of Central Asia. Tree physiology 29(6): 799-808.

Kiseleva TI, Chindyaeva LN 2011 Biology of oleaster (Elaeagnus angustifolia $\mathrm{L}$.) at the northeastern limit of its range. Contemporary Problems of Ecology 4(2): 218-222.

Klich MG 2000 Leaf variations in Elaeagnus angustifolia related to environmental heterogeneity. Environmental and Experimental Botany 44: 171-183.

Kolesnikov AI 1974 Dekorativnaya dendrologiya [Decorative dendrology]. Moscow: Lesnaya promyshlennost' [in Russian].

Kumar S, Stohlgren TJ. 2009 Maxent modeling for predicting suitable habitat for threatened and endangered tree Canacomyrica monticola in New Caledonia. Journal of Ecology and the Natural Environment 1(4): 94-98.

Lesica P, Miles S 2001 Natural history and invasion of Russian olive along eastern Montana rivers. Western North American Naturalist, 1-10.

Liang CT, Stohlgren TJ. 2011. Habitat suitability of patch types: A case study of the Yosemite toad. Frontiers of Earth Science, 5: 217-228.

Liang CT, Grasso RL, Nelson-Paul JJ, Vincent KE, Lind AJ 2017 Fine-Scale Habitat Characteristics Related to Occupancy of the Yosemite Toad, Anaxyrus canorus. Copeia 105(1): 120-127.

Liu C, Berry PM, Dawson TP, Pearson, RG 2005 Selecting thresholds of occurrence in the prediction of species distributions. Ecography, 28(3): 385-393..

Liu C, White M, Newell G 2011 Measuring and comparing the accuracy of species distribution models with presence-absence data. Ecography 34(2), 232-243.

Marsh-Matthews E, Matthews WJ, Franssen NR 2011 Can a highly invasive species re-invade its native community? The paradox of the red shiner. Biological Invasions 13(12): 2911-2924.

Merow C, Smith M., Edwards Jr TC, Guisan A, McMahon SM, Normand S, Elith J 2014 What do we gain 
from simplicity versus complexity in species distribution models? Ecography 37(12): 1267-1281.

Mikolajczak A, Maréchal D, Sanz T, Isenmann M, Thierion V, Luque S 2015 Modelling spatial distributions of alpine vegetation: A graph theory approach to delineate ecologically-consistent species assemblages. Ecological informatics 30: 196-202.

Modarres R, da Silva VDPR 2007 Rainfall trends in arid and semi-arid regions of Iran. Journal of arid environments 70(2): 344-355.

Noroozi J, Akhani H, Breckle SW 2008 Biodiversity and phytogeography of the alpine flora of Iran. Biodiversity and Conservation 17(3): 493-521.

Noroozi J, Talebi A, Doostmohammadi M, Rumpf SB, Linder HP, Schneeweiss GM 2018 Hotspots within a global biodiversity hotspot-areas of endemism are associated with high mountain ranges. Scientific reports 8 .

Olson T E, Knopf FL 1986 Naturalization of Russianolive in the western United States. Western Journal of Applied Forestry 1(3): 65-69.

Pearce CM, Smith DG, VanDevender TR, EspinosaGarcia F., Harper-Lore BL, Hubbard T 2009 Rivers as conduits for long-distance dispersal of introduced weeds: example of Russian olive (Elaeagnus angustifolia) in the northern Great Plains of North America. Invasive Plants on the Move: Controlling Them in North America 410-427.

Peterson AT, Papes M, Kluz DA 2003 Predicting the potential invasive distributions of four alien plant species in North America. Weed Science 51(6): 863868.

Rechinger KH, (ed.) 1963-2015 Flora Iranica, vols. 1-181. Akademische Druck- u. Verlagsanstalt, Graz; vol. 175. Akademische Verlagsgesellschaft, Salzburg; vols. 176-181. Verlag des Naturhistorischen Museums, Wien.

Reynolds LV, Cooper DJ 2010 Environmental tolerance of an invasive riparian tree and its potential for continued spread in the southwestern US. Journal of Vegetation Science 21(4): 733-743.

Rooper CN, Sigler MF, Goddard P, Malecha P, Towler R, Williams K, Zimmermann M 2016 Validation and improvement of species distribution models for structure-forming invertebrates in the eastern Bering Sea with an independent survey. Marine Ecology Progress Series 551: 117-130.

Saboonchian F, Jamei R, Sarghein SH 2014 Phenolic and flavonoid content of Elaeagnus angustifolia L. (leaf and flower). Avicenna journal of phytomedicine 4(4): 231.

Saupe, E. E., Barve, V., Myers, C. E., Soberón, J., Barve, N., Hensz, C. M., ... \& Lira-Noriega, A. (2012). Vari- ation in niche and distribution model performance: the need for a priori assessment of key causal factors. Ecological Modelling, 237, 11-22..

Silva Rocha I, Salvi D, Sillero N, Mateo JA, Carretero MA 2015 Snakes on the Balearic Islands: an invasion tale with implications for native biodiversity conservation. PloS one 10(4): e0121026.

Stannard M, Ogle D, Holzworth L, Scianna J, Suleaf E 2002 History, biology, ecology, suppression of Russian olive (Elaeagnus angustifolia L.). Boise, ID: USDA-NRCS 1-14.

Stratu A, Costică N, Costică M 2016 Wooden species in the urban green areas and their role in improving the quality of the environment. PESD 10(2): 173-184.

Strauss S., Webb CO, Salamin N 2006 Exotic taxa less related to native species are more invasive. Proceedings of the National Academy of Sciences 103(15): 5841-5845.

Thoma JK, Couttsa AM, Broadbenta AM, Tapper NJ 2016 The influence of increasing tree cover on mean radiant temperature across a mixed development suburb in Adelaide, Australia, Urban Forestry \& Urban Greening 20: 233-242.

Thuiller W, Georges D, Engler R 2014 biomod2: Ensemble platform for species distribution modeling. 3:164.

Thuiller W., Lafourcade B., Engler R., Araújo M.B. 2009. BIOMOD-a platform for ensemble forecasting of species distributions. Ecography 32(3): 369-373. .

Tribsch A, Schönswetter P 2003 Patterns of endemism and comparative phylogeography confirm palaeoenvironmental evidence for Pleistocene refugia in the Eastern Alps. Taxon 52(3): 477-497.

Willis AJ 2001 Endangered plants in Iran. New phytologist 149(2): 165-165.

Zhang X, Li G, Du S 2018 Simulating the potential distribution of Elaeagnus angustifolia L. based on climatic constraints in China. Ecological Engineering 113: 27-34.

Zhang X, Mi F, Lu N, Yan N, Kuglerova L, Yuan S, Ma OZ 2017 Green space water use and its impact on water resources in the capital region of China. Physics and Chemistry of the Earth, Parts A/B/C 101: 185-194.

Zhang ZD, Zang RG, Convertino M 2013 Predicting the distribution of potential natural vegetation based on species functional groups in fragmented and speciesrich forests. Plant Ecology and Evolution 146(3): 261271.

Zitzer SF, Dawson JO 1992 Soil properties and actinorhizal vegetation influence nodulation of Alnus glutinosa and Elaeagnus angustifolia by Frankia. Plant and Soil 140(2): 197-204. 


\section{Lithology legend}

ID Geo unit Description

1 Ewf Flysch with exotic blocks of Eocene limestone, Cretaceous limestone and ophiolitic components

$2 \mathrm{gb}$ Gabbro

$3 \mathrm{gb} \quad$ Layered and isotropic gabbro

4 gsch Glaucophane schist

5 h Contact metamorphic rocks: two mica Hornfels; cordierite Hornfels; andalusite-sillimanite Hornfels and locally metamorphosed carbonate rocks

$6 \mathrm{hz}$ Harzburgite

7 Island Unknown

8 Ja.bv Andesitic and basaltic volcanic rocks

9 Ja.bvt Andesitic to basaltic volcanic tuff

10 Jav Andesitic volcanic

11 Javs Andesitic volcano sediment

12 Javt Andesitic volcanic tuff

13 Jbash Shale with intercalations of sandstone

14 Jbd Dark grey, well-bedded, oolitic, ammonitiferous limestone, sandstone and shale

15 Jbg Pale-green silty shale and sandstone

16 Jbv Basaltic volcanic

17 am Amphibolite

18 ba Basalt and basaltic andesite pillow lavas

19 Cag Grey thick-bedded to massive limestone and dolomite

$20 \mathrm{Cb} \quad$ Alternation of dolomite, limestone and verigated shale

$21 \mathrm{Cd}$ Dolomite, quartzarenite, shale and limestone containing Trilobite

22 Cg Limestone, shale, dolomite and gypsum

$23 \mathrm{Cl}$ Dark red medium-grained arkosic to subarkosic sandstone and micaseous siltstone

$24 \mathrm{Cm} \quad$ Dark grey to black fossiliferous limestone with subordinate black shale

25 COm Dolomite platy and flaggy limestone containing trilobite; sandstone and shale

26 Cs Light olive-green shale with intercalations of quartzarenite and fossiliferous limestone

$27 \mathrm{Cz} \quad$ Dark red, micaceous siltstone and fine-grained sandstone

28 Czl Undifferentiated unit, composed of dark red micaceous siltstone and sandstone

29 D2met Alternation of marble, micaschist, amphibolite and quartzite

$30 \mathrm{db} \quad$ Diabase

$31 \mathrm{Db} \quad$ Grey and black, partly nodular limestone with intercalations of calcareous shale

32 Db-sh Undifferentiated limestone, shale and marl

33 DC2met Mica schist, green schist, graphite schist, and minor marble

34 DCkh Yellowish, thin to thick-bedded, fossiliferous argillaceous limestone, dark grey limestone, greenish marl and shale, locally including gypsum
ID Geo unit Description

35 DCsh Alternation of shale, marl and limestone

36 di-gb Gabbro to diorite, diorite and trondhjemite

$37 \mathrm{Dp} \quad$ Light red to white, thick bedded quartzarenite with dolomite intercalations and gypsum

38 Ds Black and grey dolomite

39 Dsb Dolomite, limestone and shale

40 Dsh Alternation of shale, marl and fossiliferous limestone, clay with intercalations of quartz arenite

$41 \mathrm{du} \quad$ Dunite

42 E Undivided Eocene rocks

43 E1-2f Lower-Middle Eocene flysch-sandstone, shale volcanoclastic sandstone, coarse grained siliceous sandstone minor limestone and pebble conglomerate

44 E1c Pale-red, polygenic conglomerate and sandstone

45 E1f Silty shale, sandstone, marl, sandy limestone, limestone and conglomerate

46 E11 Nummulitic limestone

47 E1m Marl, gypsiferous marl and limestone

48 E1s Sandstone, conglomerate, marl and sandy limestone

49 E2-3f Sandstone, calcareous sandstone and limestone

50 E2c Conglomerate and sandstone

51 E2f Sandstone, calcareous sandstone and limestone

52 E21 Nummulitic limestone

53 E2m Pale red marl, gypsiferous marl and limestone

54 E2mg Gypsiferous marl

55 E2s Sandstone, marl and limestone

56 E2sht Tuffaceous shale and tuff

57 E3c Conglomerate and sandstone

58 E3f Sandstone-shale sequence with siltstone, mudstone, limestone and conglomerate

59 E3m Marl, sandstone and limestone

60 E3sm Sandstone and marl

61 Ea.bv Andesitic and basaltic volcanic

62 Ea.bvs Andesitic to basaltic volcano sediment

63 Ea.bvt Andesitic to basaltic volcanic tuff

64 Eabvb Andesitic to basaltic volcano breccia

65 Easv Andesitic subvolcanic

66 Eat Andesitic tuff

67 Eav Unknown

68 Eav Andesitic volcanic

69 Eavb Andesitic volcano breccia

70 Eavs Andesitic volcano sediment

71 Eavt Andesitic volcanic tuff

72 Ebt Basaltic tuff

73 Ebv Basaltic volcanic rocks

74 Ebvs Basaltic volcano sediment

75 Ebvt Basaltic volcanic tuff

76 Ed.asv Dacitic to andesitic subvolcanic rocks

77 Ed.at Dacitic to Andesitic tuff

78 Ed.avb Dacitic to Andesitic volcano breccia

79 Ed.avs Dacitic to Andesitic volcano sediment

80 Edav Dacitic to Andesitic volcanic 
ID Geo unit Description

81 Edavt Dacitic andesitic volcanic tuff

82 Edi Diorite

83 Edsv Rhyolitic to rhyodacitic subvolcanic

84 Edt Rhyolitic to rhyodacitic tuff

85 Edv Rhyolitic to rhyodacitic volcanic

86 Edvb Rhyolitic to rhyodacitic volcano breccia

87 Edvs Rhyolitic to rhyodacitic volcano sediment

88 Edvt Rhyolitic to rhyodacitic volcanic tuff

89 Ef Eocene flysch in general, composed of shale, marl, sandstone, conglomerate and limestone

90 Efv Silty shale, marl, thin-bedded limestone, tuffaceous sandstone and basaltic volcanic rocks

91 Egb Gabbro

92 Egr Granite

93 Egr-di Granite to diorite

94 Eja Grey and brown weathered, massive dolomite, low weathered thin to medium -beded dolomite and massive, feature forming, buff dolomitic limestone

95 Ek Well bedded green tuff and tuffaceous shale

96 Ek.a Calcareous shale with subordinate tuff

97 Ekgy Gypsum

98 Ekh Olive-green shale and sandstone

99 Ekn Tine-bedded argillaceous limestone and calcareous shale

100 Eksh Greenish-black shale, partly tuffaceous with intercalations of tuff

101 Ekv1 Early-Eocene, sandstone, siltstone and shale with nummulitic limestone intercalation

102 Ekv2 Middle-Eocene, lower part composed of sandstone, siltstone and shale

103 Ekv3 Middle-Eocene, upper part composed of sandstone, siltstone shale and marl with limestone intercalation

104 EMas-sb Undivided Asmari and Shahbazan Formation

105 EOa-bv Andesitic to basaltic volcanic

106 EOas-ja Undivided Asmari and Jahrum Formation, regardless to the disconformity separates them

107 EOasv Eocene-Oligocene andesitic subvolcanic

108 EOav Eocene-Oligocene andesitic lava flows

109 EObv Eocene-Oligocene basaltic lava flows

110 EOd Eocene-Oligocene diorite

111 EOd-av Dacitic to Andesitic volcanic

112 EOdsv Eocene-Oligocene rhyolitic to rhyodacitic subvolcanic

113 EOdv Rhyolitic to rhyodacitic volcanic rocks

114 EOf Rytmically bedded sandstone and shale with volcanoclastic sandstone, minor limestone and tuff

115 EOgr Eocene-Oligocene granite and granodiorite

116 EOgr-d Eocene-Oligocene granite to diorite

117 EOgy Gypsum

118 EOsa Salt dome

119 EOsc Sandstone, siltstone, shale and conglomerate

120 EOt Ignembrite and tuff

121 Eph Phyllite
ID Geo unit Description

\begin{tabular}{ll}
\hline 122 Esl & Red shale and pelagic limestone \\
123 Eslv & $\begin{array}{l}\text { Red shale, pelagic limestone and amigdaloidal basic } \\
\text { volcanic rocks }\end{array}$ \\
$124 \mathrm{Jch}$ & $\begin{array}{l}\text { Dark grey argillaceous limestone and marl } \\
\text { Well-bedded to thin-bedded, greenish-grey } \\
\text { argillaceous limestone with intercalations of } \\
\text { calcareous shale }\end{array}$ \\
& Dacitic to Andesitic volcano sediment \\
$126 \mathrm{Jd} . a v s$ & Jurassic dacite to andesite lava flows \\
$127 \mathrm{Jdav}$ & Rhyolitic to rhyodacitic tuff \\
$128 \mathrm{Jdt}$ & Rhyolitic to rhyodacitic volcanic tuff \\
$129 \mathrm{Jdvt}$ & Massive, light-grey reef limestone \\
$130 \mathrm{Je}$ & Reefal limestone \\
$131 \mathrm{Jel}$ & Flysch turbidites sandstone, shale, conglomerate, \\
$132 \mathrm{Jf}$ & volcanic rocks and limestone; this unit transgresivly \\
& overlies the metamorphic rocks
\end{tabular}

$133 \mathrm{Jh}$

Alternation of sandstone and sandy to argillaceous shale with intercalations of coal and carbonaceous shale

$134 \mathrm{Jk}$ Conglomerate, sandstone and shale with plantremains and coal seams

135 JKav Andesitic flows and their associated pyroclastics with or without intercalations of limestone

$136 \mathrm{JKbl}$ Grey, thick-bedded, oolitic, fetid limestone

$137 \mathrm{Jkc}$ Honogenous, well rounded quartzos conglomerate

138 JKdi

139 JKkgp Undivided Khami Group, consist of massive thin-bedded limestone comprising the following formations: Surmeh, Hith Anhydrite, Fahlian, Gadvan and Dariyan

140 JKkgp- Jurassic to Cretaceous undivided sedimentary rocks bgp including Khami and Bagestan Groups

141 JKl Crystalized limestone and calc- schist

$142 \mathrm{Jks} \quad$ Alternation of sandstone and shale

143 JKsj Pale red argillaceous limestone, marl, gypsiferous marl, sandstone and conglomerate

$144 \mathrm{Jl} \quad$ Light grey, thin-bedded to massive limestone

$145 \mathrm{Jmz} \quad$ Grey thick-bedded limestone and dolomite

$146 \mathrm{Jph}$ Phyllite, slate and meta-sandstone (Hamadan Phyllites)

$147 \mathrm{Jq}$ Sandstone, shale, thin-bedded limestone and calcareous shale

$148 \mathrm{Jr} \quad$ Red manganiferous chert

149 Js Shale with intercalations of conglomerate, sandstone, radiolarite, limestone and volcanic

150 Jsc Conglomerate

151 Jshl.s Sandy to silty gluconitic limestone and calcareous limestone

152 Jsm Thick-bedded to massive dolomitic limestone, thinbedded argillaceous limestone and marl

153 Jss Sandstone

154 JUavs Andesitic volcano sediment

155 JUavt Andesitic volcanic Tuff 


\begin{tabular}{|c|c|c|c|c|c|}
\hline ID & Geo unit & Description & ID & Geo unit & Description \\
\hline 156 & Jub & $\begin{array}{l}\text { Sandstone, siltstone, Pectinid limestone, marl, } \\
\text { gypsum }\end{array}$ & 200 & M2gm & $\begin{array}{l}\text { Gypsiferous and calcareous marl, marlstone and } \\
\text { mudstone with interbedded siltstone and sandstone }\end{array}$ \\
\hline 157 & Juc & White, quartzous conglomerate & & & (Gushi Marl and part of Sabz unit) \\
\hline 158 & Judi & Upper Jurassic diorite & 201 & $\mathrm{M} 3 \mathrm{~ms}$ & Marl and marlstone, locally gypsiferous and \\
\hline 159 & JUdv & Rhyolitic to rhyodacitic volcanic & & & sandstone with interbedded shale and marl \\
\hline 160 & Jugn & Granite gneiss normally with augen structure & 202 & Ma.bv & Andesitic-basaltic volcanic rocks \\
\hline 161 & Jugr & Upper Jurassic granite including Shir Kuh Gra & 203 & Mat & Andesitic tuff \\
\hline & & and Shah Kuh Granite & 204 & Mav & Miocene andesitic lava flows locally basalt \\
\hline 162 & Jugr & Upper Jurassic granite including Shir Kuh Granite & 205 & $\mathrm{mb}$ & Marble \\
\hline & & and Shahkuh Granite & 206 & $\mathrm{Mbv}$ & Basaltic volcanic rocks \\
\hline 163 & Jugr-di & Upper Jurassic granite to diorite intrusive & 207 & Mc & Red conglomerate and sandstone \\
\hline 164 & Jugy & Gypsum & 208 & Mcs & Red conglomerate, sandstone, siltsto \\
\hline 165 & Jumb & Late Jurassic marble and mamorized limestone & & & mudstone \\
\hline 166 & Jupl & Pectinid limestone and marl & 209 & Md.av & Dacitic to andesitic subvolcanic rocks \\
\hline 167 & Jurb & Sandstone, siltstone, and fine-grained conglomerate & 210 & Mdt & Rhyolitic to rhyodacitic tuff \\
\hline 168 & Jus & Red sandstone and siltstone & 211 & Mgr & Granite \\
\hline 169 & $\mathrm{~K}$ & Cretaceous rocks & 212 & Mgs & Anhydrite, salt, grey and red marl alternating with \\
\hline 170 & $\mathrm{~K} 1-2 \mathrm{~lm}$ & Albian-Cenomanian marl and argillaceous limestone & & & anhydrite, argillaceous limestone and limestone \\
\hline 171 & Kla.bv & Andesitic and basaltic volcanic rocks & 213 & $\mathrm{Mm}, \mathrm{s}, \mathrm{l}$ & Marl, calcareous sandstone, sandy limestone and \\
\hline 172 & Klavt & Andesitic volcanic tuff & & & \\
\hline 173 & $\mathrm{~K} 1 \mathrm{bl}$ & Grey, thick-bedded to massive oolitic limestone & 214 & $\mathrm{Mmn}$ & Unknown \\
\hline 174 & K1bv & Early-Cretaceous basaltic lava flows & 215 & $\mathrm{Mmn}$ & $\begin{array}{l}\text { Low weathering gray marls alternating with bands of } \\
\text { more resistant shelly limestone }\end{array}$ \\
\hline 175 & K1bvt & Basaltic volcanic tuff & & & \\
\hline 176 & $\mathrm{~K} 1 \mathrm{c}$ & Red conglomerate and sandstone & 216 & Mms & $\begin{array}{l}\text { Alternations of marl, silty clay shale, sandstone and } \\
\text { dolomitic limestone }\end{array}$ \\
\hline 177 & K11 & Massive to thick-bedded orbitolina limestone & 217 & MPa.bv & Andesitic to basaltic volcanic \\
\hline 178 & $\mathrm{~K} 1 \mathrm{~m}$ & s limestone; tile red sandstone & 218 & MPa.bvt & Andesitic to basaltic volcanic tuff \\
\hline & & and gypsiferous marl & 219 & MPasv & Andesitic subvolcanic \\
\hline 179 & K2a.bv & Andesitic and basaltic volcanic rocks & 220 & MPd.av & Dacitic to andesitic volcanic \\
\hline 180 & K2asv & Andesitic subvolcanic & 221 & MPLav & Andesitic volcanic \\
\hline 181 & K2av & Andesitic volcanic & 222 & MPlc & Polymictic conglomerate, sandstone and mudstone \\
\hline 182 & K2bv & Basaltic volcanic & 223 & MPLdvt & Rhyolitic to rhyodacitic volcanic tuff \\
\hline 183 & $\mathrm{~K} 2 \mathrm{c}$ & Conglomerate and sandstone & 224 & & FARS GROUP comprising the following for \\
\hline 184 & K2d.asv & Dacitic to andesitic subvolcanic rocks & & IVIFIIgP & Gachsaran, Mishan and Aghajari, \\
\hline 185 & K2d.av & Dacitic to Andesitic volcanic & 225 & MPls & sandstone with siltstone, mudstone and minor \\
\hline 186 & K2di & Diorite & & & conglomerate \\
\hline 187 & $\mathrm{~K} 2 \mathrm{gb}$ & Gabbro & 226 & Ms & Sandstone siltstone with minor conglomerate \\
\hline 188 & K2gr & Granite & 227 & Msc & Varigated gypsiferous clay shale; conglomerate and \\
\hline 189 & $\mathrm{~K} 2 \mathrm{l}$ & Hyporite bearing limestone & & & sandstone \\
\hline 190 & $\mathrm{~K} 2 \mathrm{l}, \mathrm{m}, \mathrm{s}$ & Limestone, marl and sandstone & 228 & MuPlaj & Brown to grey, calcareous, feature-forming sandstone \\
\hline 191 & K211 & Hyporite bearing limestone & & & and low weathering, gypsum- veined, red marl and \\
\hline 192 & $\mathrm{~K} 2 \mathrm{l} 2$ & Thick-bedded to massive limestone & & & siltstone \\
\hline 193 & $\mathrm{~K} 2 \mathrm{~lm}$ & Pale-red marl, gypsiferous marl and limestone & 229 & Mur & Red marl, gypsiferous marl, sandstone and \\
\hline 194 & $\mathrm{~K} 2 \mathrm{~m}, \mathrm{l}$ & Marl, shale and detritic limestone & & & conglomerate \\
\hline 195 & & & 230 & Murc & Red conglomerate and sandstone \\
\hline & & intercalations of limestone & 231 & Murgy & Gypsum \\
\hline 196 & Ka.bv & Andesitic to basaltic volcanic & 232 & Murm & Light-red to brown marl and gypsiferous marl with \\
\hline 197 & $\mathrm{Kab}$ & Blue-grey marl and shale & & & sandstone intercal \\
\hline 198 & M1f & Rhytmically bedded sandstone, calcareous sandstone, & 233 & Murmg & Gypsiferous marl \\
\hline & & mudstone, gypsiferous mudstone and shale & 234 & Mursh & Varigated shale, gypsiferous marl and sandstone \\
\hline 199 & $\mathrm{M} 2-3 \mathrm{~s}$ & Sandstone, siltstone, conglomerate, shale, mudstone & 235 & $\mathrm{Mv}$ & Volcanic in general \\
\hline & & and shell beds & 236 & Mvs & Tuff interbedded with sandstone and siltstone \\
\hline
\end{tabular}




\begin{tabular}{|c|c|c|}
\hline 238 & Oa.bvs & Andesitic to basaltic volcano sediment \\
\hline 239 & Oasv & Andesitic subvolcanic \\
\hline 240 & Oat & Andesitic tuff \\
\hline 241 & Oav & Oligocene andesitic lava flows \\
\hline 242 & Oavt & Andesitic volcanic tuff \\
\hline 243 & Obv & Basaltic Volcanic \\
\hline 244 & Oc & Polimictic conglomerate, sandstone and siltstone \\
\hline 245 & Od.asv & Dacitic to andesitic subvolcanic rocks \\
\hline 246 & Od.av & Dacitic to andesitic volcanic \\
\hline 247 & Odi & Diorite \\
\hline 248 & Odi-gb & Diorite to gabbro \\
\hline 249 & Odsv & Rhyolitic to rhyodacitic subvolcanic \\
\hline 250 & Odv & Rhyolitic to rhyodacitic volcanic \\
\hline 251 & Odvb & Rhyolitic to rhyodacitic volcano breccia \\
\hline 252 & Odvs & Rhyolitic to rhyodacitic volcano sediment \\
\hline 253 & Odvt & Rhyolitic to rhyodacitic volcanic tuff \\
\hline 254 & Ogb & Gabbro \\
\hline 255 & Ogr & Granite \\
\hline 256 & Ogr-di & Granite to diorite \\
\hline 257 & Ogrsv & Granite subvolcanic \\
\hline 258 & Olav & Rhyolitic to rhyodacitic volcanic rocks \\
\hline 259 & Olc,s & Conglomerate and sandstone \\
\hline 260 & Olgr & Oligocene granite and granodiorite \\
\hline 261 & Olgy & Gypsum \\
\hline 262 & $\mathrm{Olm}, \mathrm{s}, \mathrm{c}$ & $\begin{array}{l}\text { Red and green silty, gypsiferous marl, sandstone and } \\
\text { gypsum }\end{array}$ \\
\hline 263 & om 1 & $\begin{array}{l}\text { Tectonized association of peridotites, gabbro, diorite, } \\
\text { trondhjemite, diabase and basic volcanic }\end{array}$ \\
\hline 264 & om2 & $\begin{array}{l}\text { Tectonized association of pelagic limestone, } \\
\text { radiolarian chert, radiolarian shale with basic } \\
\text { volcanic and intrusive rocks of ophiolitic rocks }\end{array}$ \\
\hline 265 & om3 & $\begin{array}{l}\text { Pelagic limestone, radiolarian chert and shale in } \\
\text { association with basalt and basaltic andesite pillow } \\
\text { lava }\end{array}$ \\
\hline 266 & OMa.bv & Andesite and andesitic lava flow \\
\hline 267 & OMap & Andesitic pyroclastic rocks \\
\hline 268 & OMas & $\begin{array}{l}\text { Cream to brown-weathering, feature-forming, well- } \\
\text { jointed limestone with intercalations of shale }\end{array}$ \\
\hline 269 & OMat & Andesitic tuff \\
\hline 270 & OMav & Andesitic volcanic \\
\hline 271 & OMavs & Andesitic volcano sediment \\
\hline 272 & OMbt & Basaltic tuff \\
\hline 273 & OMbv & Basalt and subvolcanic \\
\hline 274 & OMbvb & Basaltic volcano breccia \\
\hline 275 & OMbvs & Basaltic volcano sediment \\
\hline 276 & $\mathrm{OMc}$ & Basal conglomerate and sandstone \\
\hline 277 & OMd.at & Dacitic Andesitic tuff \\
\hline 278 & OMd.av & Dacitic Andesitic volcanic \\
\hline 279 & OMdi & Diorite \\
\hline 280 & OMdi-gb & Diorite to gabbro \\
\hline 281 & OMdsv & Rhyolitic to rhyodacitic subvolcanic \\
\hline 282 & OMdv & Rhyolite and rhyodacite \\
\hline
\end{tabular}

\begin{tabular}{|c|c|c|}
\hline & & \\
\hline & OMavs & Khyolitic to rhyodacitic volcano sediment \\
\hline 34 & OMdvt & Rhyolitic to rhyodacitic volcanic tuff \\
\hline 285 & OMf & $\begin{array}{l}\text { Rhytmically bedded sandstone and shale, with minor } \\
\text { siltstone and mudstone }\end{array}$ \\
\hline 286 & OMgb & Oligo-Miocene gabbro and microgabbro \\
\hline 287 & OMgr & Oligo-Miocene granite and granodiorite \\
\hline 288 & OMgr-di & Granite to diorite \\
\hline 289 & OMl & Unknown \\
\hline 290 & $\mathrm{OMq}$ & $\begin{array}{l}\text { Limestone, marl, gypsiferous marl, sandymarl and } \\
\text { sandstone }\end{array}$ \\
\hline 91 & OMql & Massive to thick-bedded reefal limestone \\
\hline 292 & OMqm & Marl with intercalations of limestone \\
\hline 293 & $\mathrm{OMr}$ & $\begin{array}{l}\text { Red, grey, and green silty marls interbedded with } \\
\text { subordinate silty limestone and minor sandstone ribs }\end{array}$ \\
\hline 294 & OMrb & $\begin{array}{l}\text { Red Beds composed of red conglomerate, sandstone, } \\
\text { marl, gypsiferous marl and gypsum }\end{array}$ \\
\hline 295 & OMssh & $\begin{array}{l}\text { Yellow-green shale and sandstone locally with } \\
\text { limestone intercalation }\end{array}$ \\
\hline 296 & OMz1 & $\begin{array}{l}\text { Alternation of varigated siltyclay shale with } \\
\text { sandstone }\end{array}$ \\
\hline 297 & $\mathrm{OMz} 2$ & $\begin{array}{l}\text { Massive to thick bedded tuffaceous sandstone and } \\
\text { varigated shale }\end{array}$ \\
\hline 298 & $\mathrm{OMz3}$ & Alternation of sandstone with siltstone and claystone \\
\hline 299 & OPLavs & Andesitic volcano sediment \\
\hline 300 & OS & Undifferentiated Ordivician and Silurian rocks \\
\hline 301 & P34 & Unknown \\
\hline 302 & $\mathrm{P}$ & Undifferentiated Permian rocks \\
\hline 303 & PAav & Andesitic volcanic \\
\hline 304 & PAbv & Basaltic volcanic \\
\hline 305 & PAbvt & Basaltic volcanic Tuff \\
\hline 306 & PAdv & Rhyolitic to rhyodacitic volcanic \\
\hline 307 & PAEa.bv & Andesitic to basaltic volcanic \\
\hline 308 & PAEa.bvt & Andesitic to basaltic volcanic tuff \\
\hline 309 & PAEav & Andesitic volcanic \\
\hline 310 & PAEavb & Andesitic volcano breccia \\
\hline 311 & PAEavs & Andesitic volcano sediment \\
\hline 312 & PAEavt & Andesitic volcanic tuff \\
\hline 313 & PAEbvs & Basaltic volcano sediment \\
\hline 314 & PAgr & Granite \\
\hline 315 & PAgr-di & Granite to diorite \\
\hline 316 & $\mathrm{pC}-\mathrm{C}$ & $\begin{array}{l}\text { Late proterozoic-early Cambrian undifferentialed } \\
\text { rocks }\end{array}$ \\
\hline 317 & pC-Cd & $\begin{array}{l}\text { Recrystalised dolomite and fetid limestone; violet- } \\
\text { red micaceous sandstone and siltstone; gypsum }\end{array}$ \\
\hline 318 & $\mathrm{pC}-\mathrm{Ch}$ & $\begin{array}{l}\text { Rock salt, gypsum \& blocks of contorted masses of } \\
\text { sedimentary material such as black laminated fetid } \\
\text { limestone, brown cherty dolomite, red sandstone } \\
\text { \& varigated shale in association with igneous rocks } \\
\text { such as diabase, basalt, rhyolite and trachyte }\end{array}$ \\
\hline 319 & $\mathrm{pC}-\mathrm{Cs}$ & $\begin{array}{l}\text { Thick dolomite and limestone unit, portly cherty } \\
\text { with thick shale intercalations }\end{array}$ \\
\hline 320 & pCa.bv & Andesite and basalt \\
\hline 321 & pCam & Amphibolite \\
\hline
\end{tabular}




\begin{tabular}{|c|c|c|}
\hline 322 & pCav & Andesitic volcanic \\
\hline 323 & pCbr & Dolomite and sandstone \\
\hline 324 & pCdi & Precambrian diorite \\
\hline 325 & $\mathrm{pCdv}$ & Rhyolitic to rhyodacitic volcanic \\
\hline 326 & pCgn & $\begin{array}{l}\text { Gneiss, granite gneiss and locally including } \\
\text { migmatite }\end{array}$ \\
\hline 327 & $\mathrm{pCgr}$ & Precambrian granite to granodiorite \\
\hline 328 & pCgr-di & Granite to diorite \\
\hline 329 & $\mathrm{pCk}$ & $\begin{array}{l}\text { Dull green grey slaty shales with subordinate } \\
\text { intercalation of quartzitic sandstone }\end{array}$ \\
\hline 330 & $\mathrm{pCmb}$ & Marble \\
\hline 31 & pCmt1 & Medium-grade, regional metamorphic rocks \\
\hline 332 & pCmt2 & Low-grade, regional metamorphic rocks \\
\hline 333 & $\mathrm{pCph}$ & Phyllite \\
\hline 334 & $\mathrm{pCr}$ & $\begin{array}{l}\text { Dolomite and limestone, partly cherty; redish sandy } \\
\text { shale and sandstone, volcanic rocks and tuffs }\end{array}$ \\
\hline 335 & pCrr & Acidic volcanic rocks \\
\hline 336 & $\mathrm{pd}$ & $\begin{array}{l}\text { Peridotite including harzburgite, dunite, lerzolite and } \\
\text { websterite }\end{array}$ \\
\hline 337 & $\mathrm{Pd}$ & $\begin{array}{l}\text { Red sandstone and shale with subordinate sandy } \\
\text { limestone }\end{array}$ \\
\hline 338 & pd1 & Ulttrabasic rocks \\
\hline 339 & Pda & $\begin{array}{l}\text { Limestone, dolomite, dolomitic limestone and thick } \\
\text { layers of anhydrite in alternation with dolomite in } \\
\text { middle part }\end{array}$ \\
\hline 340 & Peasv & Andesitic subvolcanic \\
\hline 341 & Pec & Conglomerate and sandstone \\
\hline 342 & PeEck & Limestone, marl and gysiferous marl \\
\hline 43 & PeEck-kh & $\begin{array}{l}\text { Undifferentiated unit, including limestone, marl } \\
\text { shale and sandstone }\end{array}$ \\
\hline 344 & PeEf & Flysch turbidite, sandstone and calcareous mudstone \\
\hline 345 & PeEm & $\begin{array}{l}\text { Marl and gypsiferous marl locally gypsiferous } \\
\text { mudstone }\end{array}$ \\
\hline 346 & PeEpd & $\begin{array}{l}\text { Blue and purple shale and marl interbedded with the } \\
\text { argillaceous limestone }\end{array}$ \\
\hline 347 & PeEph & Phyllite \\
\hline 348 & PeEps-ck & $\begin{array}{l}\text { Undifferentiated unit, including conglomerate, } \\
\text { sandstone, limestone and marl }\end{array}$ \\
\hline 349 & PeEs & Arkosic to subarkosic sandstone \\
\hline 350 & PeEsa & $\begin{array}{l}\text { Pale red marl, marlstone, limestone, gypsum and } \\
\text { dolomite }\end{array}$ \\
\hline 51 & PeEsh & Shale and calcareous shale \\
\hline 352 & PeEtz & $\begin{array}{l}\text { Grey and brown, medium-bedded to massive } \\
\text { fossiliferous limestone }\end{array}$ \\
\hline 353 & $\mathrm{PeEz}$ & Reef-type limestone and gypsiferous marl \\
\hline 354 & Pel & Medium to thick-bedded limestone \\
\hline 355 & Pem & Marl, gypsiferous marl and limestone \\
\hline 356 & Pems & $\begin{array}{l}\text { Mudstone calcareous shale, limestone and minor } \\
\text { sandstone }\end{array}$ \\
\hline 357 & Peps & $\begin{array}{l}\text { Red well consolidated conglomerate, sandstone and } \\
\text { mudstone }\end{array}$ \\
\hline 358 & Pes & Sandstone, calcareous shale and mudstone \\
\hline
\end{tabular}

ID Geo unit Description

359 Pgf Polygenic conglomerate, red sandstone and sandy mudstone

360 Pgkc Light-red coarse grained, polygenic conglomerate with sandstone intercalations

361 pgr Plagiogranite

$362 \mathrm{Pj} \quad$ Massive to thick-bedded, dark-grey, partly reef type limestone and a thick yellow dolomite band in the upper part

363 Pla.bv Andesitic to basaltic volcanic

364 Plasv Pliocene andesitic subvolcanic

365 Plat Andesitic tuff

366 Plav Andesitic lavas with minor basaltic andesite, tuff and breccias interbedded with volcanoclastic sandstone and boulder conglomerate (Bazman Volcanism)

367 Plbk Alternating hard of consolidated, massive, feature forming conglomerate and low -weathering cross -bedded sandstone

368 Plbv Basaltic lava flows

$369 \mathrm{Plc}$

Polymictic conglomerate and sandstone

$370 \mathrm{Plc}$

Polymictic conglomerate and sandstone

371 Pld.asv

372 Pld.at

Dacitic to andesitic subvolcanic rocks

373 Pld.av

Dacitic andesitic tuff

374 Pld.avs

375 Pldsv

376 Pldt

377 Pldv

378 Pldvt

379 Plgr

380 Plgr-di

Dacitic andesitic volcanic

Dacitic andesitic volcano sediment

Pliocene rhyolitic to rhyodacitic subvolcanic

Rhyolitic to rhyodacitic tuff

Rhyolitic to rhyodacitic volcanic

Rhyolitic to rhyodacitic volcanic tuff

Granite

381 Plmb1 Pyroclastics and claystone with vertebrate fauna remains

382 Plmb2 Ash flows and associated rocks

383 Plmb3 Ash flows and associated pyroclastic rocks, conglomerate, sandstone and shale

384 Plms Marl, shale, sandstone and conglomerate

385 PlQabv Andesite, andesitic basalt and olivine basalt

386 PlQap Silty clay, sand, gravel and volcanic ash

387 PlQav Andesitic volcanic

388 PlQavs Andesitic volcanic in association with sedimentary rocks

389 PlQbv Basaltic volcanic

390 PlQc Fluvial conglomerate, Piedmont conglomerate and sandstone.

391 PlQd.avt Dacitic andesitic volcanic tuff

392 PlQdv Rhyolitic to rhyodacitic volcanic

393 PlQlu Unfolded, poorly consolidated, yellowish silt, sand and gravel

$394 \mathrm{PlQm} \quad$ Lacustrine terraces fine grained deposits and lake sediments

395 PlQms Poorly cemented, unindurated sandstone and mudstone

$396 \mathrm{Pmb} \quad$ Marble 
ID Geo unit Description

$397 \mathrm{Pml} \quad$ Slightly metamorphosed fossiliferous (Fusulinid)

limestone, locally crystaline limestone

398 Pn Dark grey limestone and shale

$399 \operatorname{Pr} \quad$ Dark grey medium-bedded to massive limestone

400 Psch1 Metamorphosed turbidite including phyllite, crystaline limestone calc-schist

401 Psch2 Metamorphosed turbidite in associated with met ultrabasic and basic rock

402 PTR Undifferentiated Permo-Triassic sedimentary rocks

$403 \mathrm{px} \quad$ Pyroxenite

$404 \mathrm{Pz} \quad$ Undifferentiated lower Paleozoic rocks

405 Pzla.bv Andesitic basaltic volcanic

406 Pzlav Andesitic volcanic

407 Pzldi Lower Paleozoic diorite

408 Pzlgn Gneiss and anatectic granite

409 Qft1 High level piedmont fan and valley terrace deposits

$410 \mathrm{TRml}$ Meta- limestone, meta-quartzarenite, phyllite and meta- volcanic

411 Pz2 Undifferentiated Upper Paleozoic rocks

412 PZ2a.bv Andesitic basaltic volcanic

413 PZ2asv Andesitic subvolcanic

414 PZ2bv Basaltic volcanic

415 PZ2bvt Basaltic volcanic tuff

416 PZ2gr Granite

417 Pzkb Undifferentiated basic schist pelitic schist, psammitic schist, calc-silicate rocks, amphibolite, recrystalized limestone, marble and phyllite

418 Qabv Andesite to basaltic volcanic

419 Qabvs Andesitic to basaltic volcano sediment

420 Qal Stream channel, braided channel and flood plain deposits

421 Qasv Andesitic subvolcanic

422 Qat Andesitic tuff

423 Qav Andesitic volcanic Basaltic volcanic

424 Qavs Andesitic volcano sediment

425 Qba Silty clay, sandy tuff and fresh water limestone

426 Qbv Olivine basalt and basalt related to Bazman Volcanism and partly related to Taftan Volcanism

427 Qbvs Basaltic volcano sediment

428 Qcf Clay flat

429 Qcsm Clay salt marsh

430 Qcu Cultivated area

431 Qdi Diorite

432 Qdt Rhyolitic to rhyodacitic tuff

433 Pzlgr Lower Paleozoic granite, including Zarigan granite and Narigan granite

434 Pzlmt Gneiss, anatectic granite, amphibolite, kyanite, staurolite schist, quartzite and minor marble

435 Qft1 High level piedmont fan and valley terrace deposits 436 Qft1 High level piedmont fan and valley terrace deposits 437 Qft2 Low level piedmont fan and valley terrace deposits 438 Qft2 Low level piedmont fan and valley terrace deposits
ID Geo unit Description

439 Qft2 Low level piedmont fan and valley terrace deposits

440 Qft2 Low level piedmont fan and valley terrace deposits

$441 \mathrm{Qft} 2 \quad$ Low level piedmont fan and valley terrace deposits

442 Qft2 Low level piedmont fan and valley terrace deposits

443 Qft2 Low level piedmont fan and valley terrace deposits

$444 \mathrm{Qft} 2$ Low level piedmont fan and valley terrace deposits

445 Qft2 Low level piedmont fan and valley terrace deposits

446 Qft2 Low level piedmont fan and valley terrace deposits

447 Qft2 Low level piedmont fan and valley terrace deposits

448 Qgb Gabbro

449 Qgr Granite

450 Qitd Intertidal deposits

451 Qm Swamp and marsh

452 Qmt Undifferentiated marine terraces

453 QPLavt Andesitic volcanic tuff

454 QPLdasv Dacitic to andesitic subvolcanic rocks

455 Qs Sand dunes and sand sheet

456 Qs,d Unconsolidated wind-blown sand deposit including sand dunes

457 Qsf Salt flat

458 Qsl Salt Lake

459 Qsw Swamp

460 Qtr Teravertine

461 Qvc Coarse grained fanglomerate composed of volcaniclastic materials locally with intercalation of lava flows

462 sea Unknown

$463 \mathrm{sm} 1 \quad$ Sedimentary melange-sheared and boudined sediments with no recognizable stratigraphy containing tectonic blocks of Cretaceous to Eocene age

$464 \mathrm{sm} 2 \quad$ Sedimentary melange-sheard and boudined sediments with norecognisable stratigraphy, containing tectonic blocks of Cretaseous to Miocene age

$465 \mathrm{Sn} \quad$ Greenish grey, shale, sandstone, sandylime, coral limestone and dolomite

$466 \mathrm{sp} \quad$ Spilitic rocks locally with pillow structure

467 sp 1

$468 \mathrm{spr}$

$469 \mathrm{sr}$

$470 \mathrm{tm}$

Spilite spilitic andesite and diabasic tuff

Sub-marine, vesicular basalt, locally with pillow structure in association with radiolarian chert Serpentinite

Tectonic melange-association of ophiolitic components, pelagic limestone, radiolarian chert and shale with or without Eocene sedimentary rocks

471 TRa.bv Triassic, andesitic and basaltic volcanic

472 TRav Andesitic Volcanic

473 TRavt Andesitic volcanic tuff

474 TRba Red to light green conglomerate and microconglomerate with intercalations of sandstone and shale

475 TRbv Basaltic volcanic

476 TRdl Crystaline limestone and dolomite 
ID Geo unit Description

477 TRe thick bedded grey oolitic limestone; thin-platy, yellow to pinkish shaly limestone with worm tracks and well to thick-bedded dolomite and dolomitic limestone

478 TRe1 Thin bedded, yellow to pinkish argillaceous limestone with worm tracks

479 TRe2 Thick bedded dolomite

480 TRJa.bv Andesitic to Basaltic Volcanic

481 TRJlr Grey, thin to thick bedded, partly cherty, neritic limestone intercalation of radiolarian shale and chert

482 TRJs Dark grey shale and sandstone

483 TRJvm Meta-volcanic, phyllites, slate and meta- limestone

484 TRkk-nz Thin to medium-bedded, dark grey dolomite; thinbedded dolomite, greenish shale and thin-bedded argillaceous limestone

485 TRKubl Kuh Bistoon limestone

486 TRKurl Purple and red thin-bedded radiolarian chert with intercalations of neritic and pelagic limestone

487 TRmi Shale and sandstone with coal seams

488 Qft1 High level piedmont fan and valley terrace deposits

489 TRn Sandstone, quartz arenite, shale and fossiliferous limestone

490 TRn1 Grey green shale, siltstone and feldspathic sandstone underlain by pisolitic iron laterite horison

491 TRn2 Shale, Heterastridum bearing limestone and reddishbrown sandstone

492 TRn3 Shale interbedded with thin sandstone beds

493 TRn4 Black limestone, shale and sandstone

494 TRn5 Shale, siltstone, sandstone and thin sandy limestone with thin coal seams

495 TRqa Red to brown shale, sandstone and conglomerate

496 TRs Calcareous red shale

497 TRsh Well-bedded, dense, yellow dolomite

498 TRsi Tuffaceous sandstone, tuffaceous shale with intercalations of limestone, marl and conglomerate

499 TRuJm Transitional zone composed of phyllite with intercalations of crystalized limestone and acidic volcanic horizons

$500 \mathrm{Kad}$ White-cream Inoceramus bearing cherty and glauconitic argillaceous limestone

501 Kad-ab Undifferentiated unit including argillaceous limestone, marl and shale

502 Kat Olive green glauconitic sandstone and shale

503 Kav Andesitic volcanic

504 Kavt Andesitic volcanic tuff

505 Kbgp Undivided Bangestan Group, mainly limestone and shale, Albian to Companian, comprising the following formations: Kazhdumi, Sarvak, Surgah and Ilam

506 Kbsh Dark grey slightly phyllitized shale with intercalations of sandstone and limestone

$507 \mathrm{Kbv} \quad$ Basaltic volcanic

508 Kbvt Basaltic volcanic tuff

509 Kd.av Dacitic to Andesitic volcanic
ID Geo unit Description

$510 \mathrm{Kda}-\mathrm{fa}$ Grey to brown, partly oolitic, massive limestone; limestone in alternation with marl and thick-bedded to massive orbitolina bearing limestone

511 Kdi Diorite

512 Kdzsh Marl, shale, sandstone and limestone

513 KEpd-gu Grey and brown, medium-bedded to massive fossiliferous limestone

514 Kfsh Dark grey argillaceous shale

$515 \mathrm{Kgb}$ Gabbro

$516 \mathrm{Kgr} \quad$ Granite

$517 \mathrm{Kgu} \quad$ Bluish grey marl and shale with subordinate thinbedded argillaceous -limestone

$518 \mathrm{Kk} \quad$ Buff, thick-bedded limestone, marlstone and marl

$519 \mathrm{Kkz} \quad$ Grey to dark grey bituminous shale with intercations of limestone

$520 \mathrm{Kl} \quad$ Lower Cretaceous undifferentiated rocks

521 Klav Andesitic volcanic rocks

$522 \mathrm{Klsm}$ Marl, shale, sandy limestone and sandy dolomite

$523 \mathrm{Kl}$ sol Grey thick-bedded to massive orbitolina limestone

$524 \mathrm{Knl}$ Massive grey to black limestone

$525 \mathrm{Kns} \quad$ Red sandstone and conglomeratic sandstone

526 Knsh Dark green calcareous shale

$527 \mathrm{Knz} \quad$ Gloconitic sandstone

528 KPAavs Andesitic Volcano sediment

529 KPeam Dark olive-brown, low weathered siltstone and sandstone with local development of chert conglomerates and shelly limestone

$530 \mathrm{KPedu}$ Undifferentiated limestone, basic to intermediate lava and pillow lava, metavolcanic, phyllite, schist, sediments, metasediments with minor tuff and intrusive rocks

531 KPef Thinly bedded sandstone and shale with siltstone, mudstone limestone and conglomerate

532 KPefv Crystal tuff, tuffaceous sandstone, recrystalized limestone and sandy limestone, red chert and pillow lava

533 KPegr Late Cretaceous-Early Paleocene granite

534 KPegr-di Late Cretaceous-Early Paleocene granite to diorite intrusive rocks

535 KPeph Phyllite

$536 \mathrm{KPvs} \quad$ Volcanic and volcanoclastic rocks including tuff, basalt, minor conglomerate and slamp breccia

$537 \mathrm{Ksm}, \mathrm{l}$ Marl and calcareous shale with intercalations of limestone

538 Ksn Grey to block shale and thin layers of siltstone and sandstone

$539 \mathrm{Ksr} \quad$ Ammonite bearing shale with interaction of orbitolin limestone

$540 \mathrm{Ksv} \quad$ Grey, thick-bedded to massive limestone with thin marl intercalations in upper part

$541 \mathrm{Ktb} \quad$ Massive, shelly, cliff-forming partly anhydritic limestone 
ID Geo unit Description

$542 \mathrm{Ktl} \quad$ Thin to medium bedded argillaceous limestone and thick bedded to massive, grey orbitolina bearing limestone

$543 \mathrm{Ktr} \quad$ Grey oolitic and bioclastic orbitolina limestone

$544 \mathrm{Ktzl}$ Thick bedded to massive, white to pinkish orbitolina bearing limestone

$545 \mathrm{Ku} \quad$ Upper cretaceous, undifferentiated rocks

546 Kuabv Late-Cretaceous andesitic and basaltic lava flows

547 Kuavs Andesitic Volcano sedimentary

548 Kuf Unknown

549 Kuf Flysch type sediments including shale, sandstone, limestone and conglomerate

550 Kufsh Mudstone, shale and sandstone

551 Kuft Flysch turbidites

552 Kufv Flysch-volcanic rocks

553 Kugr Granite and granodiorite

554 Kugr-di Granite to Diorite

555 Kupl Globotrunca limestone

556 Kur Radiolarian chert and shale

557 Kurl Undifferentiated pelagic limestone and radiolarian chert

558 Kus Flysch turbidite sandstone with interbed calcareous mudstone and shale

559 Kussh Dark grey shale

560 Kussh Dark grey shale

5611 Massive, recrystalized limestone with minor phyllite and schist

562 L.E-Oa. Andesitic to basaltic volcanic bv

563 L.E-Oa. Andesitic to basaltic volcanic tuff bvt

564 L.E-Oav Andesitic volcanic

565 L.E-Obv Basaltic volcanic

566 L.E-Od.atDacitic to andesitic tuff

567 L.E-Od. Dacitic to andesitic volcanic av

568 L.E-Od. Dacitic to andesitic volcano breccia avb

569 L.E-Od. Dacitic to andesitic volcanic tuff avt

570 L.E-Odi Diorite

571 L.E-Odsv Late Eocene-Early Oligocene rhyolitic to rhyodacitic subvolcanic rocks

572 L.E-Odv Rhyolitic to rhyodacitic volcanic

573 L.E-Of Feldespatoidal intrusive rock

574 L.E-Ogr Late Eocene-Early Oligocene granite

575 Lake Unknown

$576 \mathrm{lv} \quad$ Listvinite

577 M1-2f Thickly bedded sandstone with interbedded siltstone and shale

578 M1-2m Shale, gypsiferous shale, gypsiferous mudstone and silty shale with minor sandstone and limestone

\section{Soil order legend}

\begin{tabular}{ll}
\hline ID & Soil order \\
\hline 1 & Inceptisols/Vertisols \\
2 & Inceptisols \\
3 & Entisols/Inceptisols \\
4 & Entisols/Aridisols \\
5 & Aridisols \\
6 & Rock outcrops/ Inceptisols \\
7 & Rock outcrops/Entisols \\
8 & Playa \\
9 & Rocky lands \\
10 & Kalut \\
11 & Dune lands \\
12 & Marsh \\
13 & Coastal sands \\
14 & Bad lands \\
15 & Mollisols \\
16 & Water body \\
17 & Urban \\
18 & Salt plug \\
19 & Salt flats \\
20 & Alfisols \\
\hline &
\end{tabular}

